\title{
Two new Morganella species from the Brazilian Amazon rainforest
}

\author{
Alfredo $\mathrm{DS}^{1^{*}}$, Leite $\mathrm{AG}^{2}$, Braga-Neto $\mathrm{R}^{3}$ and Baseia $\mathrm{IG}^{2}$ \\ ${ }^{1}$ Programa de Pós-graduação em Sistemática e Evolução, Centro de Biociências, Universidade Federal do Rio Grande do \\ Norte, Campus Universitário, CEP 59072-970, Natal, RN, Brazil (donis.alfredo@ yahoo.com.br) \\ ${ }^{2}$ Departamento Botânica, Ecologia e Zoologia, Centro de Biociências, Universidade Federal do Rio Grande do Norte, \\ Campus Universitário, CEP 59072-970, Natal, RN, Brazil \\ ${ }^{3}$ Departamento de Ecologia, Coordenação de Pesquisas em Ecologia, Instituto Nacional de Pesquisa da Amazônia, Av. \\ Efigênio Sales, 2239, BOX 2239, Coroado, CEP 69011-970, Manaus, AM, Brazil
}

Alfredo DS, Leite AG, Braga-Neto R, Baseia IG 2012 - Two new Morganella species from the Brazilian Amazon rainforest. Mycosphere 3(1), 66-71, Doi 10.5943/mycosphere/3/1/8

Two new Morganella species, M. albostipitata and M. rimosa were found during studies of gasteroid fungi in the Brazilian Amazon rainforest, Adolpho Ducke Forest Reserve, Amazonas State, Brazil. The new taxa are described, and illustrated with photographs and line drawings, and taxonomical comments are made.

Key words - Basidiomycota - Gasteromycetes - Neotropics - Taxonomy

\section{Article Information}

Received 6 February 2012

Accepted 7 February 2012

Published online 22 February 2012

*Corresponding author: Dônis S Alfredo - e-mail - donis.alfredo@yahoo.com.br

\section{Introduction}

Morganella Zeller is a gasteroid genus with few species described, mostly occurring in tropical regions (Kirk et al. 2008). The genus was established by Zeller (1948) through segregation of species previously accommodated in Lycoperdon and later emended by Kreisel \& Dring (1967), Ponce de Leon (1971) and Kruger \& Kreisel (2003). Fied studies are needed to expand the knowledge of this little known group of puffballs. The present study aims to provide new data on tropical species of Morganella.

The Adolpho Duke Reserve Forest (ADRF) is being inserted into the Amazon biome; one of the most studied areas of the Amazon rainforest. Recent studies on plant diversity in the ADRF report the presence of several rare and endemic species (Hopkings 2005). High plant diversity in the vegetation of the Amazon biome suggests the diversity of fungi is also significant. According to Mueller et al. (2004), vegetation influences occurrence and diversity of fungi in the environment, since plants provide a habitat and energy source for most fungi which, in turn, exhibit some degree of specificity with hosts and/or substrates.

\section{Methods}

Collections were made during the rainy seasons of 2008 and 2010 in the Adolpho Ducke Reserve Forest, Manaus, AM, Brazil. Basidiomata were examined and photographed in the field. Macro and microscopic characters were determined according to specialized literature (Zeller 1948, Kreisel \& Dring 1967, Ponce de Leon 1969, 1971, Suárez \& Wright 1996). The measurement of basidiospores and scanning electron microscopy were made according to Silva et al. (2011). Colours were coded in accordance with Kornerup \& Wanscher (1978) and vouchers are deposited in the UFRN Herbarium. 

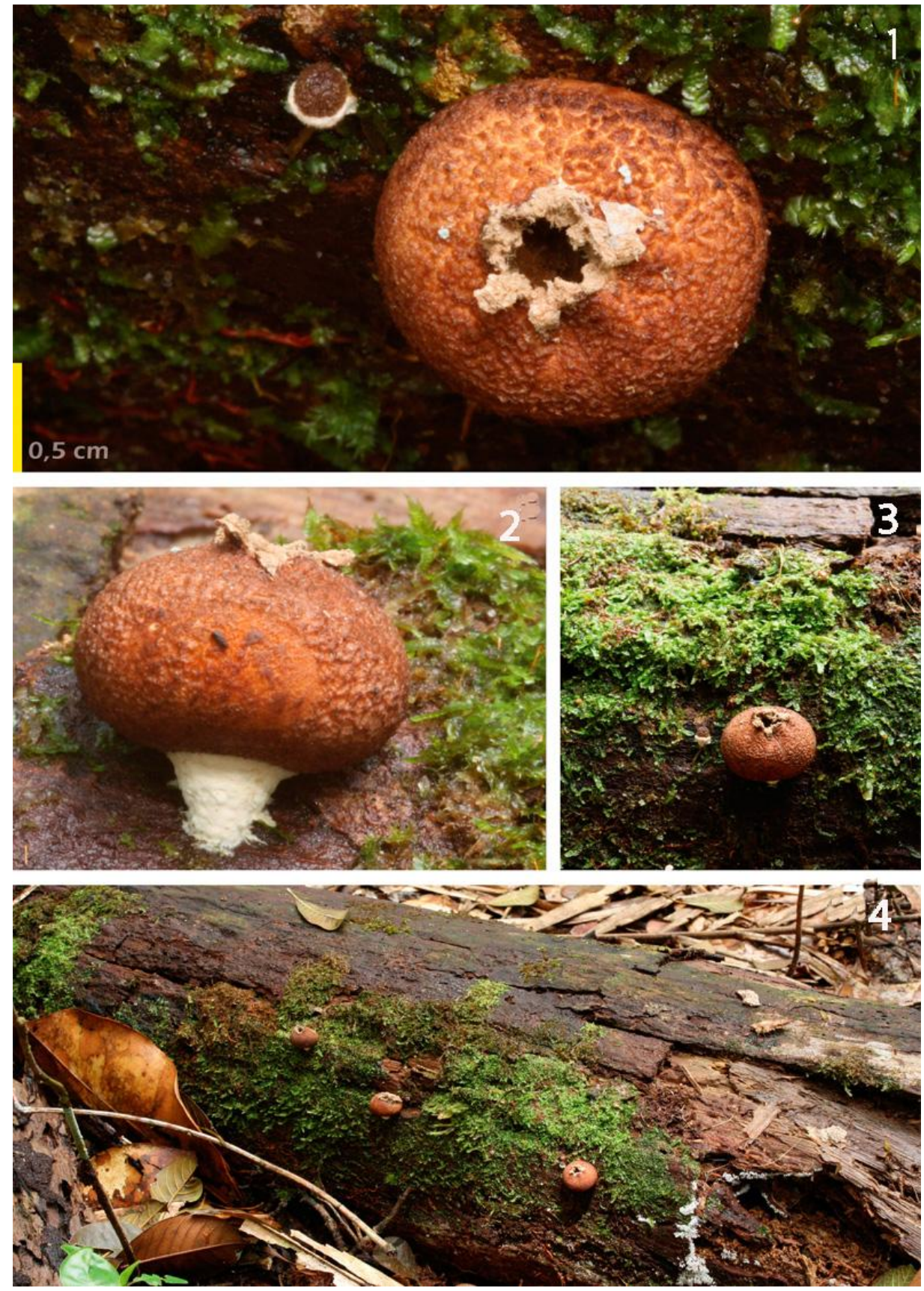

Figs 1-4 - Morganella albostipitata sp. nov. Mature basidiomata.

\section{Results}

Morganella albostipitata Baseia \& Alfredo sp. nov.

MycoBank 564373.

(http://www.mycobank.org).

Etymology - In reference to the presence of a white pseudostipite.

Basidioma juvene epigeum, depresse subglobosum vel pyriformis, $10 \mathrm{~mm}$ latum, 7 $\mathrm{mm}$ altum. Exoperidium velutinum, brunneus luteo, hyphae setaceis vel subglobosis, crassis.
Endoperidium apex cum ostiolum laceratissisimus. Subgleba magna celularis, compacta. Pseudostipite albo conspicuus. Basidiosporae globosae, 5-6 $4 \mathrm{~m}$ latum, valde echinulatae. Paracapillicio tenuis, 3-4 $\mu$ m latum, hyalinum. In sylva, solitarius.

Basidiomata 8-10 mm diam., 6-7 mm high, depressed globose to pyriform. Peridium consisting of a persistent velvety exoperidium. Exoperidium granulose, cracked forming units of tufts, brownish yellow (5E7), composed of irregular chains of thickened hyphae (10-120 

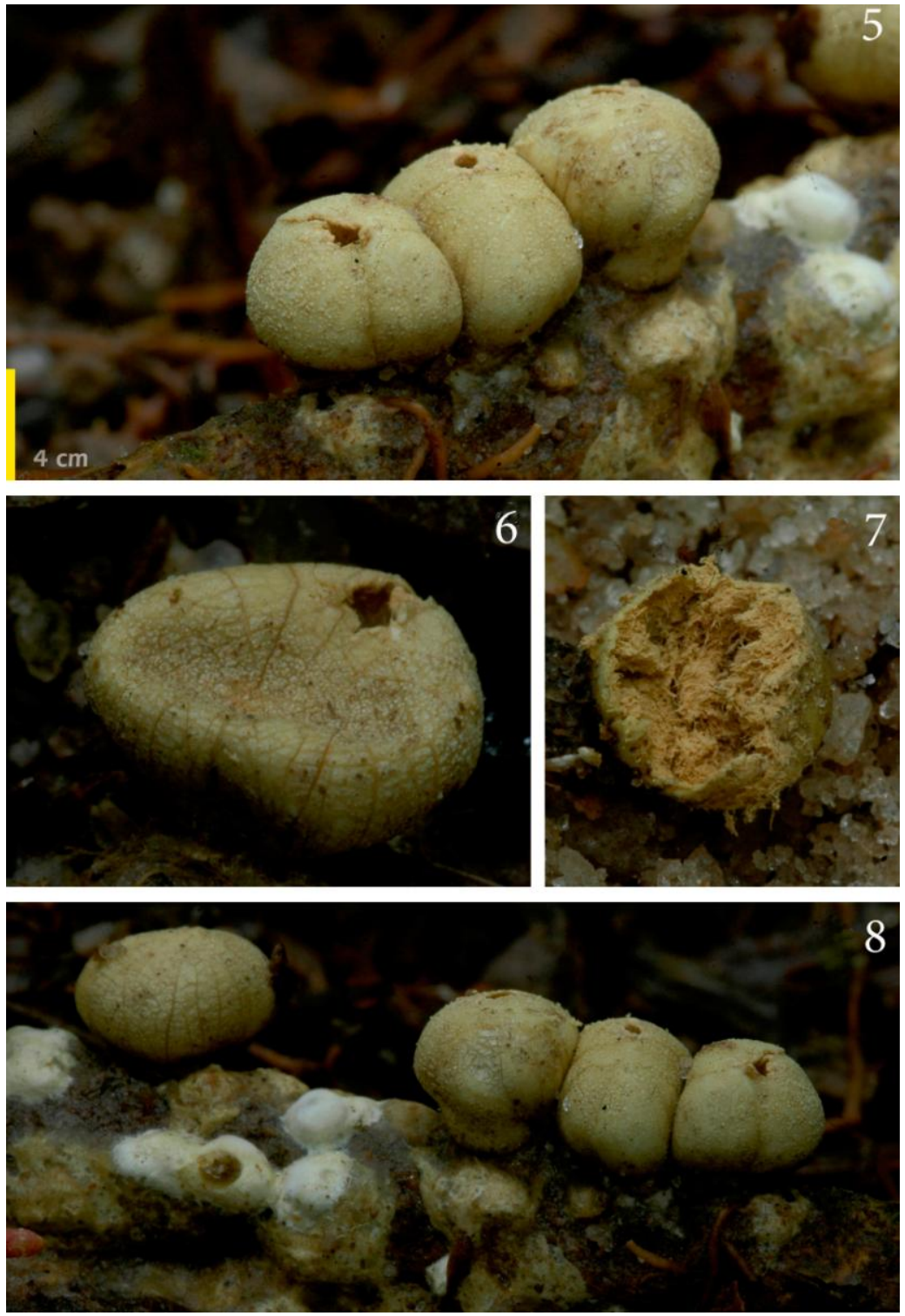

Figs 5-8-Morganella rimosa sp. nov. Mature basidiomata.

$\mu \mathrm{m}$ diam.), subglobose to setoid. Endoperidium smooth, pale yellow (4A3), dehiscing by a strongly lacerate peristome, formed from hyaline, irregular thin hyphae (20-30 $\mu \mathrm{m}$ diam.). Sterile base compact (Fig. 2b), pale brown (5D2), $2 \mathrm{~mm}$ high. Pseudostipite conspicuous (Fig. 2b), white (4A1), $4 \mathrm{~mm}$ high. Gleba brown (5D4). Rhizomorphs inconspicuous. Basidiospores 5-6 $\mu \mathrm{m}$ diam., globose, strongly equinulate, shortly pedicellate, pale brown in $5 \% \mathrm{KOH}$. Eucapillitium absent. Paracapillitium abundant, 3-4 $\mu \mathrm{m}$ diam., septate and branched, hyaline, presenting amorphous and hyaline incrustation.

Known distribution - Brazil.

Material examined - Brazil, Amazonas, Manaus Reserva Florestal Adolpho Ducke, on decaying wood, J.P.M. Araújo (GF23), R. Braga-Neto, F.F Pezzini 14 November 2010 (INPA 239563, Holotype).

Morganella rimosa Baseia \& Alfredo sp. nov. Fig. 5-8

MycoBank 564371

(http://www.mycobank.org).

Etymology - Named in reference to the peridium surface, marked with numerous cracks.

Basidioma juvene epigeum, depresse subglobosum,subsessile, 5-6 mm latum, 4.5-5.5 $\mathrm{mm}$ altum, caespitosum in subiculo albo luteo. Exoperidium granuloso et rimosissimus, albo luteo, hyphae irregularibus, crassisillimus. Endoperidium apex cum ostiolum laceratum. 

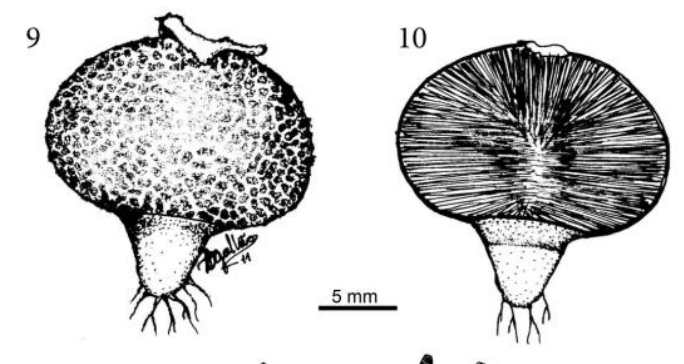

11
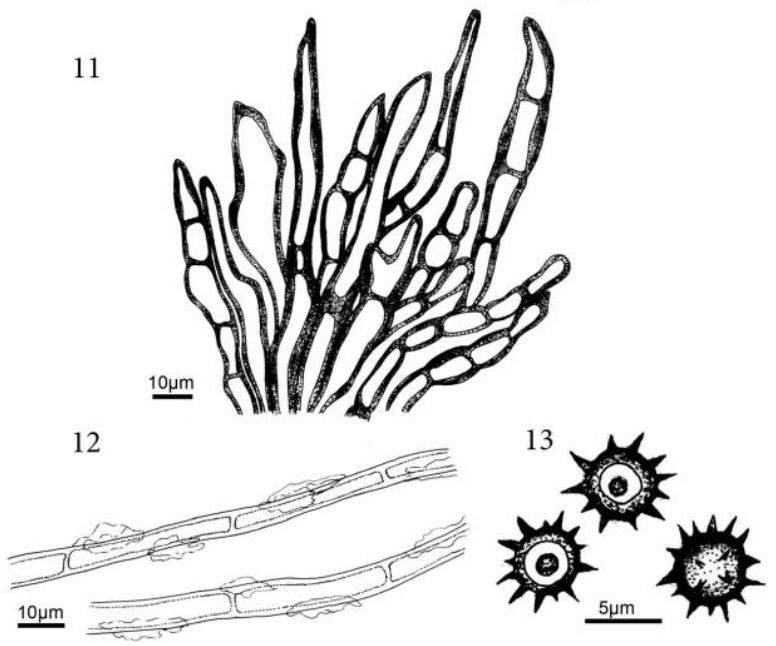

Figs 9-13 - Morganella albostipitata sp. nov. 9, 10 Mature basidiomata; 11 Exoperidium; 12 Paracapilitium; 13 Basidiospores.
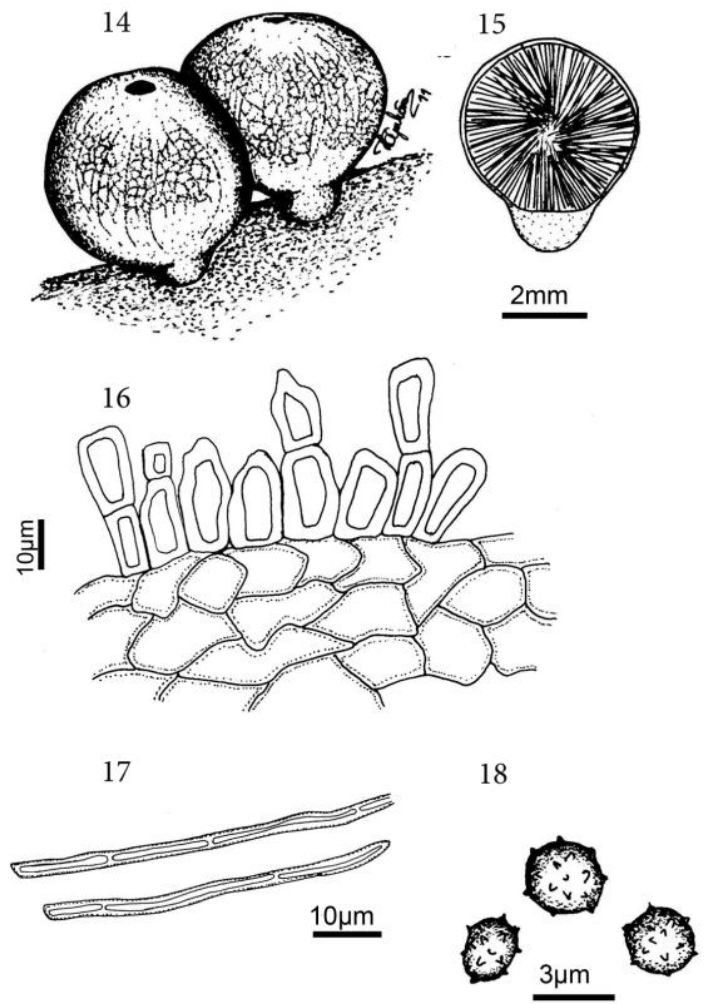

Figs 14-18 - Morganella rimosa sp. nov. 14, 15 Mature basdiomata. 16 Exoperidium. 17 Paracapilitium. 18 Basidiospores. 

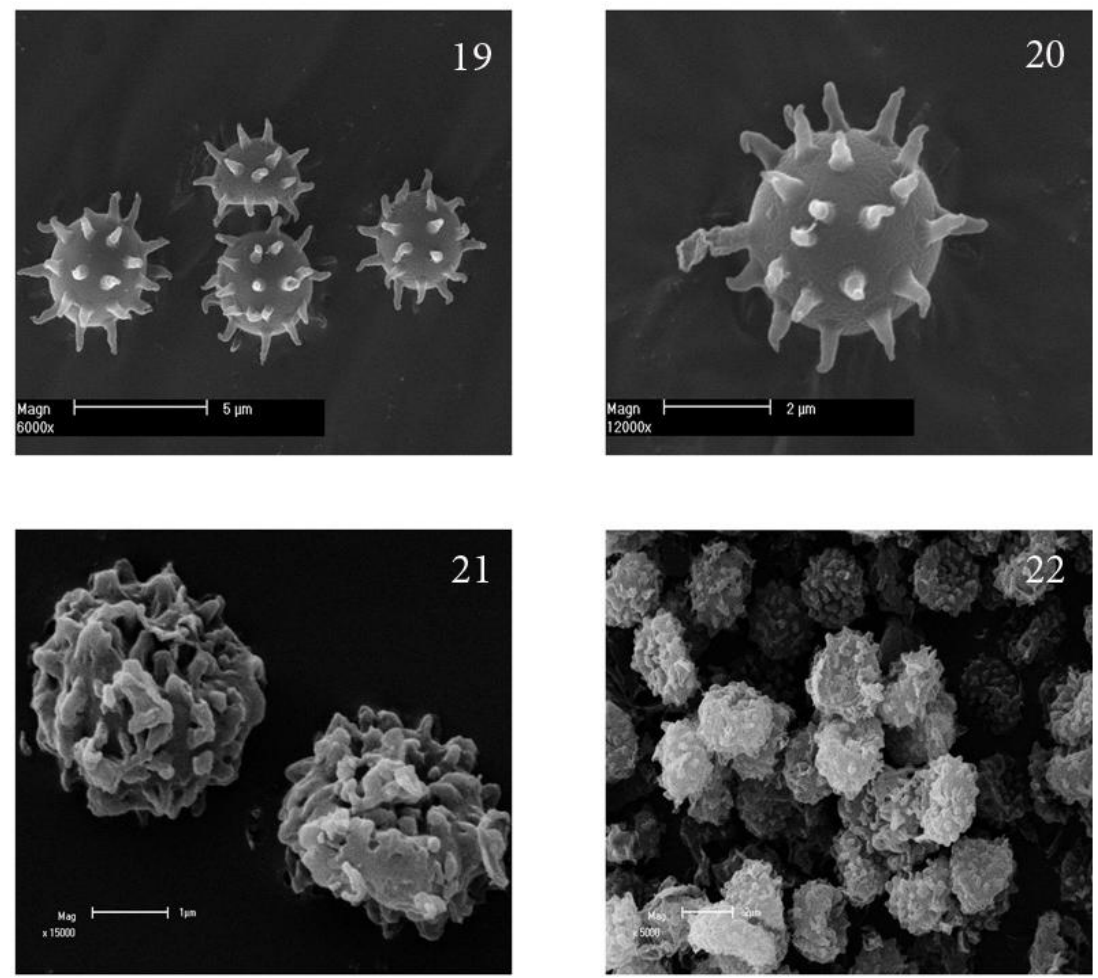

Figs 19-22 - SEM Basidiospores. 19, 20 Morganella albostipitata. 21, 22 M rimosa.

Subgleba rudimentaris, celularis, compacta Basidiosporae globosae, subglobosae vel ovoideum, 2-3 mm latum, debilis echinulatae. Paracapillicio tenuissimo, $1.5-2 \mathrm{~mm}$ latum, hyalinum. In sylva, aggregatus.

Basidiomata 5-6 mm diam., 4.5-5.5 mm high, globose to subglobose, cespitose, gregarious, growing on a subiculum pale yellow (4A2). Peridium consisting of cracked exoperidium, detaching from the endoperidium at maturity. Exoperidium rimose, granulose, pale yellow (4A3), composed of brown, irregular and thickened hyphae (8-25 $\mu \mathrm{m}$ diam.), either not in chains or forming short chains with two hyphae. Endoperidium smooth, pale yellow (4A2), dehiscing by lacerate peristome, formed from hyaline, irregular thin hyphae (7-40 $\mu \mathrm{m}$ diam.). Sterile base white (4A1), compact, 1 $\mathrm{mm}$ high. Gleba reddish yellow (A46). Basidiospores 2-3 $\mu \mathrm{m}$ diam., globose, subglobose to ovoid, verrucose to equinulate, apiculate, pale yellow in $5 \% \mathrm{KOH}$. Eucapillitium absent. Paracapillitium scarce, 1.5- $2 \mu \mathrm{m}$ diam., septate and branched, hyaline.

Known distribution - Brazil.

Material examined - BRAZIL, Amazonas, Manaus Reserva Florestal Adolpho Ducke, on decaying wood R. Braga-Neto, RBN 598, 14 November 2010 (UFRN-Fungos 1680, Holotype).

\section{Discussion}

Morganella albostipitata is easily recognized by the lignicolous basidiomata, which initially resembles $M$. fuliginea (Berk. \& M.A. Curtis) Kreisel \& Dring (1967). However, close examination reveals several distinctive characteristics: 1) white pseudostipite conspi-cuous, seemingly originating from the basal mycelium (Fig. 2 and 10); 2) exoperidium composed of chains of irregular hyphae (Fig. 11); 3) basidiospores shortly pedicellate (Fig. 13). When observed under SEM, spore ornamenttation exhibits a striate ring around the base (Fig. 3). In comparison with other Morganella species (Ponce de Leon 1971, Suárez \& Wright 1996, Bates 2004, Calonge et al. 2005, Trierveiler-Pereira et al. 2010), this character set clearly shows that $M$. albostipitata is a good species.

Morganella rimosa displays an unusual set of characters that facilitate species recognition: 1) The presence of subiculum and cespitose basidiomata (Fig. 5, 8 and 14); 2) 
cracked and granulose exoperidium (Fig. 6 and 8); 3) compacted sterile base (Fig. 15). This species can be confused with $M$. albina and Lycogalopsis solmsii (considered synonymous by Ponce de Leon, 1969). In our specimens, basidiomata grow from a white subiculum, whereas basidiomata in $M$. albina grow in isolation and have no subiculum. An additional difference is the presence of sphaerocysts in $M$. rimosa, absent in L. solmsii. According to Dring (1964) and Reid (1977) dehiscence in L. solmsii occurs through irregular dehiscence of the upper portion of the basidioma, which acquires the shape of a concave disk. This is not observed in $M$. rimosa, where dehiscence takes place through a well defined ostiole at the apex of basidiomata.

\section{Acknowledgements}

The authors thank Tereza Cristina O. Galvão and Marcelo A. Sulzbacher for the drawings. $\mathrm{CNPq}$ is acknowledged for financial support.

\section{References}

Bates ST. 2004 - Arizona members of the Geastraceae and Lycoperdaceae (Basidiomycota, Fungi). M.Sc. Tthesis, Arizona State University, Tempe.

Calonge FD, Mata M, Carranza J. 2005 Contribución al catálogo de los Gasteromycetes (Basidiomycotina, Fungi) de Costa Rica. Anales del Jardín Botánico de Madrid 62(1), 23-45.

Dring DM. 1964 - Gasteromycetes of West Tropical Africa. Mycological Papers 98.

Hopkins MJG. 2005 - Flora da Reserva Ducke, Amazonas, Brasil. Rodriguésia 56(86), 925.

Kirk PM, Cannon PF, Minter DW, Stalpers JA.
2008 - Dictionary of the fungi. $10^{\text {th }}$ Edition. CAB International, Wallingford. $771 \mathrm{pp}$.

Kornerup A, Wanscher JH. 1978 - Methuen handbook of colours. Third edition. Eyre Methuen. London. 252 pp.

Kreisel H, Dring DM. 1967 - An emendation of the genus Morganella Zeller (Lycoperdaceae). Feddes Repertorium 74, 109122.

Krüger D, Kreisel H. 2003 - Proposing Morganella subgen. Apioperdon subgen. nov. for the puffball Lycoperdon pyriforme. Mycotaxon 86, 169-177.

Mueller GM, Bills GF, Foster MS. 2004 Biodiversity of fungi: inventory and monitoring methods. Elsevier Academic Press, London. 777 pp.

Ponce de Leon P. 1969 - A new member of Morganella. Fieldiana Botany 32(6), 6971.

Ponce de Leon P. 1971 - Revision of the genus Morganella (Lycopercaceae). Fieldiana Botany 34 (3), 27-44.

Reid DA. 1977 - Some Gasteromycetes from Trinidad and Tobago. Kew Bulletin 31, 657-690.

Silva BDB, Souza JO, Baseia IG. 2011 Discovery of Geastrum xerophilum from the Neotropics. Mycotaxon 118, 355-359.

Suárez VL, Wright JE. 1996 - South American Gasteromycetes V: The genus Morganella. Mycologia 88, 655-661.

Trierveiler-Pereira L, Kreisel H, Baseia IG. 2010 - New data on puffballs (Agaricomycetes, Basidiomycota) from the northest region Brazil. Mycotaxon 111, 411-421.

Zeller SM. 1948. Notes on certain gasteromycetes, including two new orders. Mycologia 40, 639-668. 